\title{
Seston retention by Whatman GF/C glass-fiber filters
}

\author{
Wolfgang Hickel \\ Biologische Anstalt Helgoland, Notkestraße 31, D-2000 Hamburg 52, Federal Republic of Germany
}

\begin{abstract}
The efficiency of Whatman GF/C glass-fiber filters for the retention of seston (dry weight) from North Sea water was tested. Uni-Pore polycarbonate membranes with pore sizes of $0.4,1$ and $5 \mu \mathrm{m}$ diameter were used as standard 'sieve' filters, since they have well-defined pore sizes. Using means of the differences of paired filters, it was found that GF/C glass-fiber filters retain seston from North Sea samples as efficiently as $0.4 \mu \mathrm{m}$ Uni-Pore filters at a seston concentration range of about 1.5 to $15 \mathrm{mg}$ $\mathrm{dm}^{-3}$; this covers most of the German Bight water bodies in summer. Glass-fiber filters retained significantly $(P<0.001)$ more seston than $1 \mu \mathrm{m}$ Uni-Pore filters and thus more as their nominal mean retention size of $1.2 \mu \mathrm{m}$ would suggest. Comparison of seston retention of GF/C and Uni-Pore filters by regression analysis revealed that GF/C filters tend to retain relatively more seston as the water becomes clearer and sample volumes greater; this is the case in the western German Bight (Secchi depth about 7 to $9 \mathrm{~m}$, seston concentrations $<2 \mathrm{mg} \mathrm{dm}^{-3}$, sample volumes filtered: 600 to $1000 \mathrm{~cm}^{3}$ ). This higher retention of $\mathrm{GF} / \mathrm{C}$ filters is significant $(\mathrm{P}=0.05)$ when compared with $0.4 \mu \mathrm{m}$ Uni-Pore filters but highly significant $(\mathrm{P}<0.001)$ with $1 \mu \mathrm{m}$ Uni-Pore filters. This indicates that particles $<1 \mu \mathrm{m}$ contributes significantly to the seston weight in such open North Sea water It seemed unlikely. however, that adsorbed dissolved organic matter caused a 'seston' weight increase.
\end{abstract}

\section{INTRODUCTION}

Suspended particulate matter ('seston') is defined arbitrarily by an artificial separation method, mostly by filtration. In marine research, filters of about $1 \mu \mathrm{m}$ pore size are often applied, but generally the pore size of $0.45 \mu \mathrm{m}$ is considered the division point between 'dissolved' and 'particulate' (Wangersky, 1975).

Glass-fiber filters, particularly Whatman GF/C filters, are probably the most widely used filters to sample marine seston, when not only seston dry weight or pigments, but also organic carbon and nitrogen have to be analyzed. These filters are free of organic binders, do not charge electrostatically and are not hygroscopic. They have low carbon blank values - which can almost be eliminated by precombustion - and no nitrogen blank value. This and their fast filtration speed and low price compare favourably with the other alternative filter type: the silver filters (Salonen, 1979).

However, glass filters have a major drawback: they have no well defined pore size, as they consist of a rather thick (GF/C: $0.26 \mathrm{~mm}$ ) layer of borosilicate glass fibers of $<1 \mu \mathrm{m}$ diameter. From the scanning electron microscope photograph (Fig. 1) it is obvious that GF/C- filter pore sizes vary over a wide range. A mean pore size of such filters might not be a good indicator of particle size separation (Sheldon and Sutcliffe, 1969). The effective pore size must be found empirically. It could be influenced by seston quantity and particlesize distribution, as clogging of the pores may reduce the effective pore size during filtration.

The mean retention size of the Whatman GF/C filter as stated by the manufacturer is $1.2 \mu \mathrm{m}$. According to Strickland and Parsons (1968) these filters have a mean pore size of 1 to $2 \mu \mathrm{m}$. Sheldon (1972) found a median retention size of $0.7 \mu \mathrm{m}$. Riley (1970) stated no marked difference in the total catch of seston obtained by a fine glass-fiber filter as compared with $0.45 \mu \mathrm{m}$ silver filters. Lenz (1971) found the GF/C glass-fiber filters to be similar to $0.8 \mu \mathrm{m}$ membrane filters in retaining Baltic Sea seston (weight). Using particulate organic carbon as a measure, Wangersky and Hincks (1980) found that Whatman GF/C filters retained significantly more organic carbon than did $0.8 \mu \mathrm{m}$ silver filters.

Considering the structure of the glass-fiber filters, the nature of natural seston populations, and practical requirements, the usual methods of testing retention of particles by filters - using suspensions of uniformly 
sized particles at low loading rates - might not be adequate. I therefore compared the retention of North Sea seston (dry weight) by GF/C filters with that by Uni-Pore polycarbonate membranes with $0.4,1$ and 5 $\mu \mathrm{m}$ pore diameter as reference standard. Similar intercalibration of filters - using GF/C and silver filters among others - has been conducted by Wangersky and Hincks (1980).

Uni-Pore polycarbonate membranes have, similar to the widely used Nuclepore filters, pores which are etched to the desired dimensions from radiation tracks. They have a very uniform size (Fig. 1), the visible pore

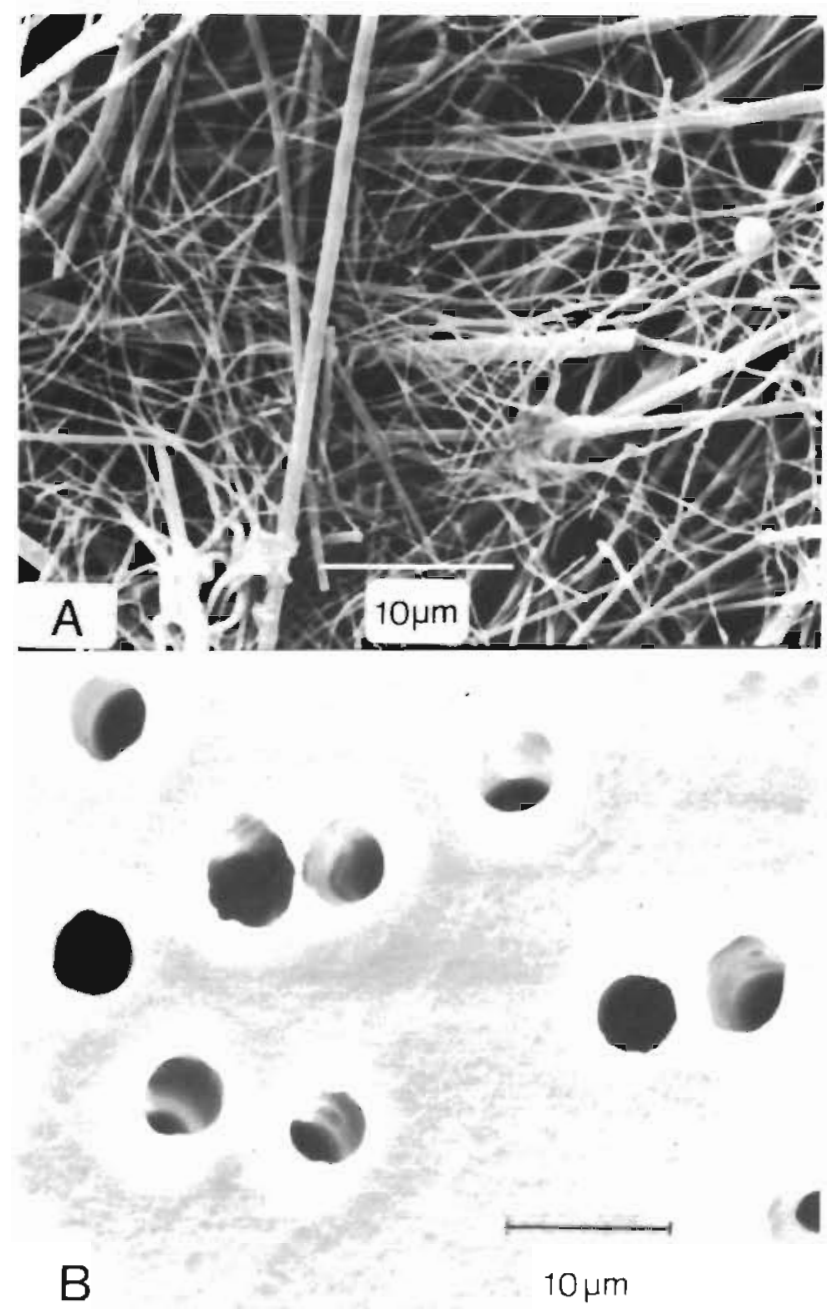

Fig. 1. (A)Glass-fiber filter (Whatman $G F / C$, nominal retention size: $1.2 \mu \mathrm{m})$. (B) Uni-Pore polycarbonate membrane filter (5 um nominal pore size). Scanning electron micrographs of the filter surfaces

diameter being the effective pore size. Such filters can be used as screens (Sheldon, 1972) as opposed to filters with spongy structures (e.g. membrane filters of cellulose acetate) or fiber filters. Sheldon found that Nucle- pore membranes had a retention size close to their nominal pore size, which does not change up to the point of overloading.

Retention characteristics of glass-fiber filters were tested under conditions routinely applied in North Sea seston studies by this author: the filters were small ( 25 $\mathrm{mm}$ diam) in order to fit into the sample boats of an CHN-analyzer (as the organic content of the seston had to be analyzed). Therefore the full loading capacity had to be used - until immediately before a rapid decrease of filtration speed indicated clogging of the pores. This point was usually reached after ca. 2 to 10 min. The filters then contained about 1 to $3 \mathrm{mg}$ of seston dry weight - enough to ensure subsequent organic carbon and nitrogen analyses at reasonable precision. These requirements excluded the use of constant water volumes filtered - as seston concentrations varied over 2 orders of magnitude - and therefore included possible errors due to different sample volumes.

\section{METHODS}

Sea water samples from 103 stations were used for this study. They were sampled during an R. V. 'Friedrich Heincke' cruise from 13 to 31 August, 1979, covering the German Bight with stations 10 nautical miles (nearshore: 5 miles) apart from each other (Fig. 2). Water was sampled with Niskin bottles. Only the uppermost sample (about $1 \mathrm{~m}$ depth) of each vertical series was used.

The whole content of the bottle was mixed and subsamples were filtered within $1 \mathrm{~h}$. Pyrex glass microfiltration units (Millipore) were used applying a vacuum of about about $1 / 3 \mathrm{~atm}$. The volume of subsamples filtered through glass-fiber filters varied from $25 \mathrm{~cm}^{3}$ (Elbe river water) to $1000 \mathrm{~cm}^{3}$; volumes of subsamples filtered through Uni-Pore filters of 3 respective pore size were max. 175,350 and $600 \mathrm{~cm}^{3}$.

The glass-fiber filters were precombusted at $490^{\circ} \mathrm{C}$ for $2 \mathrm{~h}$, after treatment with distilled water to remove loose glass fibers. Precombustion was necessary to reduce filter blank for subsequent particulate organic carbon (POC) analysis. Uni-Pore filters were soaked with distilled water and dried $\left(65^{\circ} \mathrm{C}\right)$, then weighed using a Cahn electrobalance. Blank filters were used to check weight constancy of the filters.

After filtration, filters were rinsed twice with $3 \mathrm{~cm}^{3}$ of distilled water to remove the salt. Filters were then deep frozen at $-18^{\circ} \mathrm{C}$. In the laboratory, they were treated with 3 drops of $0.1 \mathrm{~N} \mathrm{HCl}$ to remove inorganic carbon, dried at $65^{\circ} \mathrm{C}$ for $12 \mathrm{~h}$ and reweighed. This seston weight determination has a precision of \pm 0.15 mg at the $95 \%$ level of probability according to Lenz (1971). 


\section{RESULTS}

The weather was calm during the cruise. The water column of much of the German Bight showed the usual summer vertical stratification of density. Under such circumstances seston composition usually differs considerably between open German Bight, Wadden Sea and Elbe estuary waters. Seston concentrations in the present samples varied over 2 orders of magnitude from about $1 \mathrm{mg} \mathrm{dm}^{-3}$ in the western German Bight to $180 \mathrm{mg} \mathrm{dm}^{-3}$ in the Elbe estuary. These 3 water masses (Fig. 2) have therefore been separately treated statistically; they may be characterized as follows:

(1) German Bight water had a salinity $>27 \%$. The water-column ranged between 10 and $40 \mathrm{~m}$; it was hydrographically stratified in some areas. Large phyto- plankton stocks were found. Secchi disc visibility ranged from 1.5 to $9.0 \mathrm{~m}$, seston weight ( $\mathrm{GF} / \mathrm{C}$ filter) from 1.0 to $8.5 \mathrm{mg} \mathrm{dm}^{-3}$.

(2) North Frisian Wadden Sea water (north of Eiderstedt peninsula) is shallow and turbulent; strong tidal currents resuspend sedimented matter, and after storms, eroded fossil material from cliffs adds to the seston stock. Secchi depth ranged from 1.1 to $7.0 \mathrm{~m}$, seston weight from 2.1 to $15.3 \mathrm{mg} \mathrm{dm}^{-3}$. Sampling was done in the main tidal channels (often $>10 \mathrm{~m}$ deep); some stations were repeated.

(3) Elbe estuary water was separated from 'German Bight' water by a salinity $<27 \%$; this included the Meldorfer Bucht. A turbidity maximum - characteristic for this type of estuary - is found off Brunsbuittel (innermost Elbe stations); seston loads are 1 order of mag-

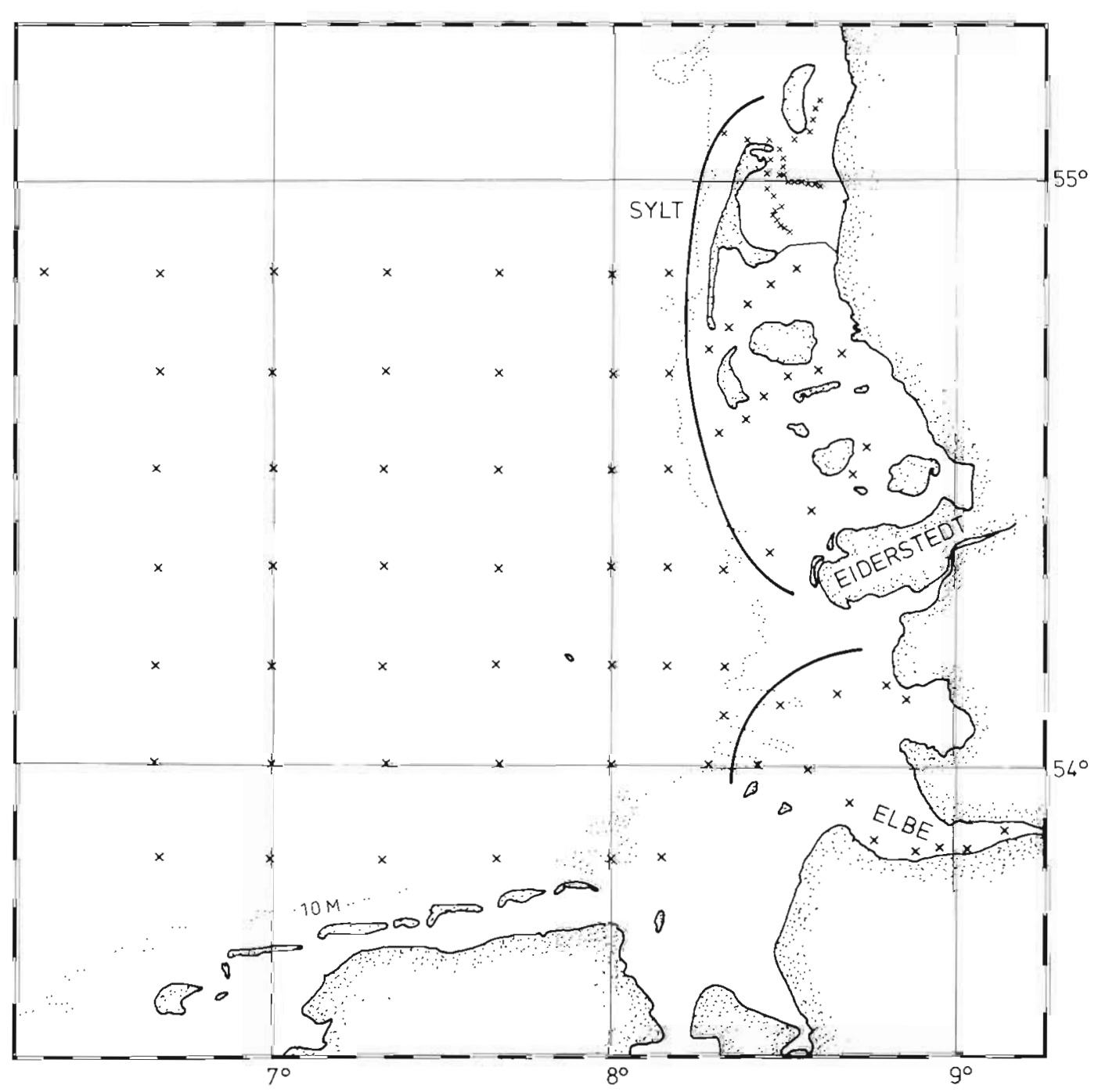

Fig. 2. German Bight, North Sea: sampling stations during R. V. 'Friedrich Heincke' cruise, 13 to 31 August, 1979 . Solid lines separate water masses distinguished here 
nitude higher here than in the remainder of the coastal waters. They ranged from 10 to $182 \mathrm{mg} \mathrm{dm}^{-3}$; corresponding Secchi depths ranged from 1.6 to $0.2 \mathrm{~m}$.

Seston retained by GF/C glass-fiber filters was compared with seston retained by standard sieve filters
(Uni-Pore membranes of 3 different pore sizes). Fig. 3 illustrates this comparison for the 3 water masses. Seston weights $\left(\mu \mathrm{g} \mathrm{dm}^{-3}\right.$ ) were transformed to $\log _{10}$ (seston weight) to bring their frequency distribution closer to normality.
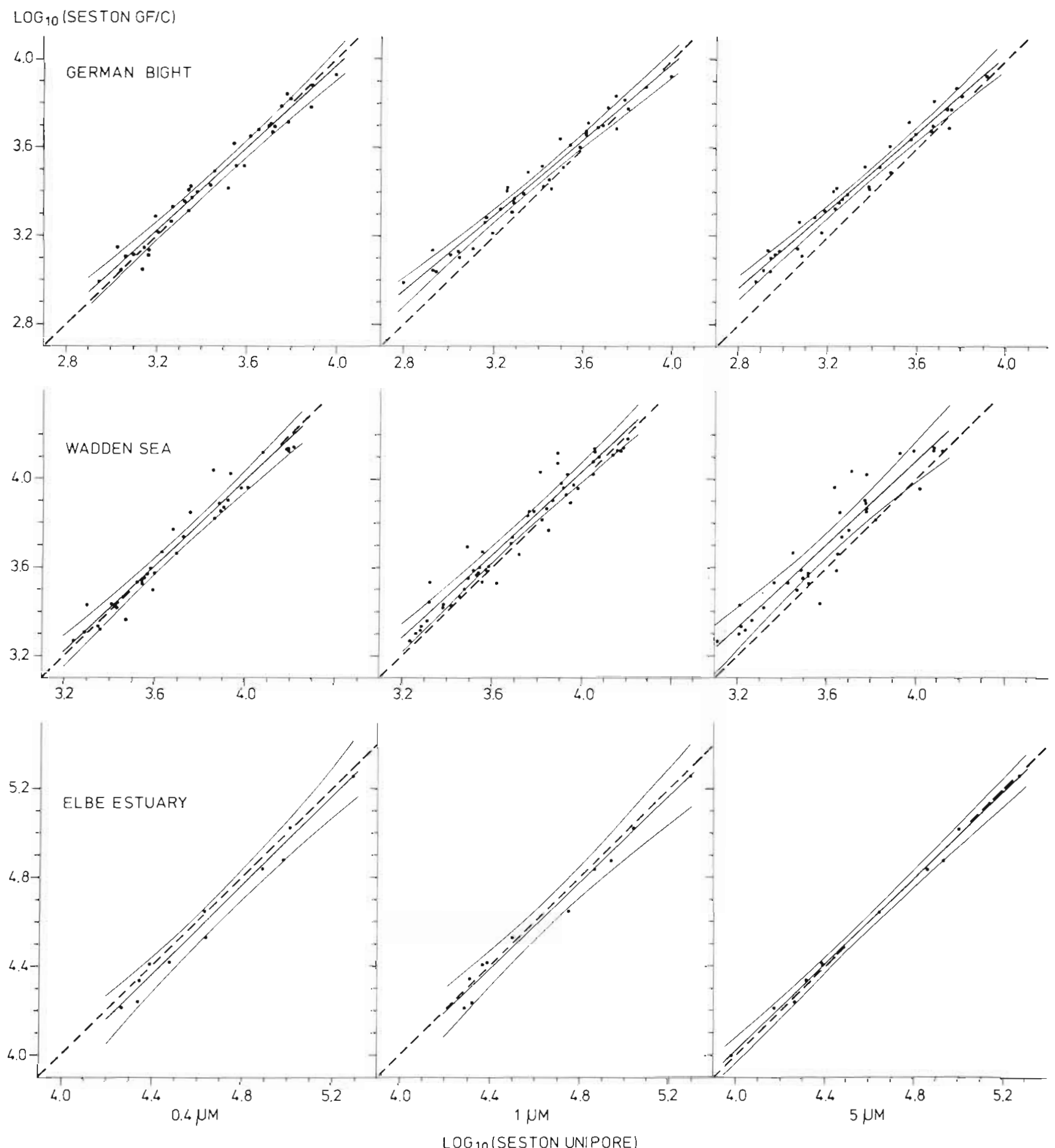

Fig. 3. Comparison of seston dry weight retained by Whatman GF/C glass-fiber filters (ordinate) and Uni-Pore membranes with $0.4,1$ and $5 \mu \mathrm{m}$ pore size (abszissa). Seston dry weights $\left(\mu \mathrm{m} \mathrm{dm}^{-3}\right)$ transformed to $\log _{10}$ (seston weight). Regression lines and their $95 \%$-confidence belts for 3 water masses. Hatched: line of equality $(Y=X)$ 
Table 1. Comparison between $\log _{10}$ (seston $\mathrm{GF} / \mathrm{C}$ ) (Y) and $\log _{10}$ (seston Uni-Pore filter) (X): mean values of filters $\pm 95 \%$ confidence limits. GF/C glass-fiber filters contain significantly $(P<0.001)$ more seston than Uni-Pore filters of 1 and $5 \mu m$ pore diameter in German Bight and Wadden Sea waters, but contain as much seston as a $0.4 \mu m$ Uni-Pore filters (means of the differences of individual filter pairs, tested by paired t-test). ${ }^{\cdot}$ significant at the $5 \%$ level; ${ }^{\cdots}$ at the $0.1 \%$ level

\begin{tabular}{|c|c|c|c|c|c|c|c|c|c|}
\hline & \multicolumn{3}{|c|}{$\begin{array}{l}\text { German Bight } \\
\text { Uni-Pore filter }\end{array}$} & \multicolumn{3}{|c|}{$\begin{array}{l}\text { Wadden Sea } \\
\text { Uni-Pore filter }\end{array}$} & \multicolumn{3}{|c|}{$\begin{array}{l}\text { Elbe estuary } \\
\text { Uni-Pore filter }\end{array}$} \\
\hline & 0.4 & 1.0 & 5.0 & 0.4 & 1.0 & 5.0 & 0.4 & 1.0 & 5.0 \\
\hline $\mathrm{n}=$ & 38 & 39 & 37 & 35 & 53 & 36 & 11 & 11 & 11 \\
\hline$x$ & $\begin{array}{c}3.4447 \\
\pm \\
0.0935\end{array}$ & $\begin{array}{c}3.3929 \\
\pm \\
0.0968\end{array}$ & $\begin{array}{c}3.3431 \\
\pm \\
0.1005\end{array}$ & $\begin{array}{c}3.7153 \\
\pm \\
0.0971\end{array}$ & $\begin{array}{c}3.7212 \\
\pm \\
0.0783\end{array}$ & $\begin{array}{c}3.6105 \\
\pm \\
0.0920\end{array}$ & $\begin{array}{c}4.6608 \\
\pm \\
0.2258\end{array}$ & $\begin{array}{c}4.6440 \\
\pm \\
0.2354\end{array}$ & $\begin{array}{c}4.5679 \\
\pm \\
0.2709\end{array}$ \\
\hline $\mathrm{Y}$ & $\begin{array}{c}3.4457 \\
\pm \\
0.0886\end{array}$ & $\begin{array}{c}3.4586 \\
\pm \\
0.0847 \\
\ldots\end{array}$ & $\begin{array}{c}3.4390 \\
\pm \\
0.0900 \\
\ldots\end{array}$ & $\begin{array}{c}3.7136 \\
\pm \\
0.0952\end{array}$ & $\begin{array}{c}3.7649 \\
\pm \\
0.0757 \\
\ldots\end{array}$ & $\begin{array}{c}3.7102 \\
\pm \\
0.0927 \\
\ldots\end{array}$ & $\begin{array}{c}4.6203 \\
\pm \\
0.2295 \\
.\end{array}$ & $\begin{array}{c}4.6203 \\
\pm \\
0.2295\end{array}$ & $\begin{array}{c}4.5716 \\
\pm \\
0.2620\end{array}$ \\
\hline
\end{tabular}

To evaluate these differences statistically, a paired t-test for the means of the differences between filter pairs was used. I tested the hypothesis: no difference between mean seston weight retention by glass-fiber and Uni-Pore filters of the respective pore size (Table 1). In addition, linear regression analysis was employed. The hypothesis was tested: $b=1$ resp. $a=0$, which means that both filters retain the same amount of seston over the whole concentration range. This can be evaluated from regression lines, their $95 \%$-confidence belts (Fig. 3) and from Table 2.

From the mean difference between filter pairs and confidence limits (Table 1) as well as from the paired t-test it is evident that GF/C glass-fiber filters retain highly significant $(\mathrm{P}<0.001)$ more seston than UniPore filters of 1 and $5 \mu \mathrm{m}$ pore size with German Bight and Wadden Sea waters. In the Elbe estuary, however, $\mathrm{GF} / \mathrm{C}$ filters retain significantly less $(\mathrm{P}=0.05)$ seston than a $0.4 \mu \mathrm{m}$ pore-size filter.
Retention characteristics of GF/C glass-fiber filters resemble those of $0.4 \mu \mathrm{m}$ Uni-Pore filters very closely in German Bight and Wadden Sea waters. In the Elbe estuary, glass-fiber filter seston retention was closest to that of $5 \mu \mathrm{m}$ Uni-Pore filters but not significantly different from $1 \mu \mathrm{m}$ Uni-Pore filters.

Additional information is gained from regression analysis. In case of identical seston retention by 2 filters, data points (Fig. 3) should not deviate significantly from the line of equality $\mathrm{Y}=\mathrm{X}$ (broken lines in Fig. 3). Regression lines fitted to data points do, however, deviate from this line; the regression coefficient is less than 1 in German Bight samples (Table 2), as data points tend to lie above the line of equality at lower seston concentrations. This indicates that relatively more seston is retained by a GF/C filter than by a Uni-Pore filter in clear, seston-poor water in the deeper parts of the western German Bight (filtered sample volumes: 600 to $1000 \mathrm{~cm}^{3}$ ). This is particularly signifi-

Table 2. Regression analysis of filter pairs. Y $\left(\log _{10}\right.$ [seston $\left.\left.\mathrm{GF} / \mathrm{C}\right]\right)=\mathrm{a}+\mathrm{b} X\left(\log _{10}[\right.$ seston Uni-pore]). Correlation coefficients, $\mathrm{Y}$ intercepts and regression coefficients $\pm 95 \%$ confidence limits. $\cdot \cdots$ : a- and b-values significantly different from their hypothetical value 0 and 1 , resp., at the $5 \%$ resp. $0.1 \%$ level

\begin{tabular}{|c|c|c|c|c|c|c|c|c|c|}
\hline & \multicolumn{3}{|c|}{$\begin{array}{l}\text { German Bight } \\
\text { Uni-Pore filter }\end{array}$} & \multicolumn{3}{|c|}{$\begin{array}{l}\text { Wadden Sea } \\
\text { Uni-Pore filter }\end{array}$} & \multicolumn{3}{|c|}{$\begin{array}{l}\text { Elbe estuary } \\
\text { Uni-Pore filter }\end{array}$} \\
\hline & 0.4 & 1.0 & 5.0 & 0.4 & 1.0 & 5.0 & 0.4 & 1.0 & 5.0 \\
\hline $\mathrm{n}=$ & 38 & 39 & 37 & 35 & 53 & 36 & 11 & 11 & 11 \\
\hline $\mathrm{r}$ & 0.9821 & 0.9816 & 0.9829 & 0.9766 & 0.9668 & 0.9356 & 0.9894 & 0.9894 & 0.9980 \\
\hline $\mathrm{a}$ & $\begin{array}{c}0.2404 \\
\pm \\
0.2090 \\
\cdot\end{array}$ & $\begin{array}{c}0.5450 \\
\pm \\
0.1895 \\
\ldots\end{array}$ & $\begin{array}{c}0.4965 \\
\pm \\
0.1898 \\
\ldots\end{array}$ & $\begin{array}{c}0.1565 \\
\pm \\
0.2782\end{array}$ & $\begin{array}{c}0.2859 \\
\pm \\
0.2594 \\
\cdot\end{array}$ & $\begin{array}{c}0.3101 \\
\pm \\
0.4492\end{array}$ & $\begin{array}{c}-0.0674 \\
\pm \\
0.5191\end{array}$ & $\begin{array}{c}0.1399 \\
\pm \\
0.4980\end{array}$ & $\begin{array}{c}0.1640 \\
\pm \\
0.2134\end{array}$ \\
\hline $\mathrm{b}$ & $\begin{array}{c}0.9305 \\
\pm \\
0.0605 \\
.\end{array}$ & $\begin{array}{c}0.8588 \\
\pm \\
0.0556 \\
\ldots\end{array}$ & $\begin{array}{c}0.8802 \\
\pm \\
0.0565 \\
\ldots\end{array}$ & $\begin{array}{c}0.9574 \\
\pm \\
0.0747\end{array}$ & $\begin{array}{c}0.9349 \\
\pm \\
0.0695\end{array}$ & $\begin{array}{c}0.9417 \\
\pm \\
0.1416\end{array}$ & $\begin{array}{c}1.0058 \\
\pm \\
0.1111\end{array}$ & $\begin{array}{c}0.9648 \\
\pm \\
0.1070\end{array}$ & $\begin{array}{c}0.9649 \\
\pm \\
0.0466\end{array}$ \\
\hline
\end{tabular}


cant ( $\mathrm{P}<0.001$ ) when $\mathrm{GF} / \mathrm{C}$ filters are compared with 1 and $5 \mu \mathrm{m}$ Uni-Pore filters.

\section{DISCUSSION}

'Seston' values evaluated by glass-fiber filters must be interpreted cautiously for 2 reasons: possible adsorption of dissolved and colloidal matter to the glass fibers and changing retention characteristics of the filter during filtration by clogging of the pores. What is actually retained as 'seston' depends on filter pore size, including its reduction during filtration, and on its adsorbing surfaces and the chemical nature of subparticulate matter. As this paper deals with seston retention in North Sea coastal waters with high and variable seston concentrations, no constant water volumes could be filtered in order to avoid errors due to different sample volumes.

From mean values (Table 1) it appears that $\mathrm{GF} / \mathrm{C}$ glass-fiber filters retain not only all seston $>1 \mu \mathrm{m}-$ their nominal mean retention size being $1.2 \mu \mathrm{m}-$ but also particles down to $0.4 \mu \mathrm{m}$. This includes much of the 'colloidal' fraction defined as 0.001 to $1 \mu \mathrm{m}$ particles. At least the organic colloidal matter in seawater seems to be 1 order of magnitude more concentrated than the organic particulate fraction $>1 \mu \mathrm{m}$ (Mullin, 1965, Sharp 1973).

The regression coefficients $<1$ and $Y$-intercepts $>0$ - as found in 'German Bight' samples (Table 2) indicate either diminishing effective pore sizes of glass-fiber filters during filtration - and thus retention of ever smaller particles - as filtered volumes become greater, or increasing portions of very fine particles, or adsorption of dissolved matter. This deviation of the regression coefficients and $Y$-intercepts from their hypothetical values 1 and 0 are highly significant $(\mathrm{P}<0.001)$ only when GF/C and $1 \mu \mathrm{m}$ Uni-Pore filters are compared. With $0.4 \mu \mathrm{m}$ Uni-Pore filters this difference is smaller (significant only at $P=0.05$ ). This supports the assumption that it was 'colloidal' matter $<1$, mostly $>0.4 \mu \mathrm{m}$, which caused the relative seston weight increase with $\mathrm{GF} / \mathrm{C}$ filters in this clearest water of the western German Bight, or open North Sea (Secchi depths 7 to $9 \mathrm{~m}$, less than $2 \mathrm{mg} \mathrm{dm}^{-3}$ seston, sample volumes filtered: $>500 \mathrm{~cm}^{3}$ ).

Additional evidence for this hypothesis comes from experiments which exclude the influence of adsorbed matter on 'seston' weight: The central patch (containing the seston) of the glass-fiber filters was cut from the margin and the latter analyzed separately for organic carbon and nitrogen. As seawater without seston will be drawn through this margin - covered by the glass filtration tube - the margin will contain amounts of adsorbed matter similar to the central filter patch.
Furthermore, a second glass-fiber filter underlying the first was used.

The result was that the adsorbed matter makes up a few percent of the particulate organic matter in plankton-rich waters. But the weight of this adsorbed matter was far too low to influence the seston weight significantly.

More often than in seston weight, marine ecologists are interested in its organic components, measured as particulate organic carbon (POC) and nitrogen (PN). Most comparisons of filters have therefore been made using $P O C$ as a criterion. This, however, excludes the use of organic Nuclepore or Uni-Pore filters with their excellent pore-size definition. I therefore used seston weight in this paper. POC and PN retention by GF/C filters have to be discussed in a further paper including the adsorption problem in more detail.

As already mentioned, maximum filter loading rates had to be used in order to collect enough material for organic matter analysis. Such 'maximum loading' could only roughly be estimated during filtration on board by the time when filtration speed slowed down rapidly. This time will depend on the quantity of seston particles lying on top of the filter or, even more, on finer particles clogging the pores.

Do the glass-fiber filters have comparable retention capacities at the time when filtration has to be stopped? Three additional experiments were conducted to test the influence of different loading rates on filterretention capacity. The water was sampled in the outer Wadden Sea of Sylt at high tide, representing North Frisian coastal water. Two samples (18 February and 9 March, 1981 containing ca. 21 and $47 \mathrm{mg}$ seston $\mathrm{dm}^{3}$ ) represented winter seston with high silt and very low plankton content. One sample (14 April, 1981 with ca. $7 \mathrm{mg}$ seston $\mathrm{dm}^{-3}$ ) was taken during a diatom bloom making up about $1 / 3$ of the organic carbon of the seston. Different subsample volumes of these samples were filtered through the GF/C glass-fiber filters and seston weight $\mathrm{dm}^{-3}$ as well as filtration time recorded.

With this type of seston the retention capacity of the $\mathrm{GF} / \mathrm{C}$ filters did not change much at the filtration time used routinely. No marked effect of different loading rates on the seston weight retained could be found during the last half of the filtration period. Such experiments should be repeated with offshore water samples from the western German Bight.

In conclusion, Whatman GF/C glass-fiber filters retain much finer particles than their nominal pore size $(1.2 \mu \mathrm{m})$ suggests. Using these filters with North Sea samples at high loading rates, they retained all 'seston' defined as $\geq 0.4 \mu \mathrm{m}$-particles.

Acknowledgements. I thank Dr. B. Hickel, Max-PlanckInstitut für Limnologie, Plön, for SEM photos of the filters. 
Careful assistance of Ms. A. Reiners is gratefully acknowledged. Dr. P. Wangersky made valuable suggestions.

\section{LITERATURE CITED}

Lenz, J. (1971). Zur Methode der Sestonbestimmung. Kieler Meeresforsch. 27: 180-193

Mullin, M. M. (1965). Size fractionation of particulate organic carbon in the surface waters of the western Indian Ocean. Limnol. Oceanogr. 10 (3): 459-462

Riley, G. A. (1970). Particulate organic matter in sea water. Adv, mar. Biol. 8: 1-118

Salonen, K. (1979). Comparison of different glass-fiber and silver metal filters for the determination of particulate organic carbon. Hydrobiologia 67 : 29-32
Sharp, J. H. (1973). Size classes of organic carbon in seawater. Limnol. Oceanogr. 18 (3): 441-447

Sheldon, R. W. (1972). Size separation of marine seston by membrane and glass-fiber filters. Limnol. Oceanogr. 17: 494-498

Sheldon, R. W., Sutcliffe, W. H., Jr. (1969). Retention of marine particles by screens and filters. Limnol. Oceanogr. 14: $441-444$

Strickland, J. D. H., Parsons, T. R. (1968). A practical handbook of seawater analysis. Bull. Fish. Res. Bd Can. 167: $1-311$

Wangersky, P. J. (1975). Measurement of organic carbon in seawater. In: Gibb, R. P., Jr. (ed.) Analytical methods in oceanography. Am. Chem. Soc., Washington, p. 148-162

Wangersky, P. J., Hincks, A. V. (1980). Shipboard intercalibration of filters used in the measurement of particulate organic carbon. In: Albaiges, J. (ed.) Analytical techniques in environmental chemistry. Pergamon Press, Oxford, New York, p. 53-62

This paper was submitted to the editor; it was accepted for printing on December 1, 1983 